\title{
Juliet's Narcissism
}

Natalie K. Eschenbaum

\section{(2) OpenEdition \\ Journals}

\section{Electronic version}

URL: http://journals.openedition.org/shakespeare/3600

DOI: 10.4000/shakespeare.3600

ISSN: 2271-6424

\section{Publisher}

Société Française Shakespeare

\section{Electronic reference}

Natalie K. Eschenbaum, « Juliet's Narcissism », Actes des congrès de la Société française Shakespeare

[Online], 33 | 2015, Online since 10 October 2015, connection on 05 June 2020. URL : http://

journals.openedition.org/shakespeare/3600; DOI : https://doi.org/10.4000/shakespeare.3600

This text was automatically generated on 5 June 2020.

(c) SFS 


\title{
Juliet's Narcissism
}

\author{
Natalie K. Eschenbaum
}

1 Juliet is the first Shakespearean girl heroine most students encounter. In the United States, Romeo and Juliet usually is introduced in high school, when students are about the same age as the lovers, and taught alongside at least one filmic adaptation: Franco Zeffirelli's 1968 version was the standard for a while; this was replaced or supplemented when Baz Luhrmann released his postmodern version in $1996 .{ }^{1}$ Luhrmann adhered to the original text, but created an MTV-like world that "captivated an international teen audience" and was the first example of what Angela Keam terms the "'Shakesteen' genre." Keam suggests that, due to the casting of the title characters (Leonardo DiCaprio and Claire Danes), Luhrmann's film was particularly appealing to "female teen viewers and perhaps help[ed] them to shape their adolescent identities." Teenage girls flocked to the theatres and continue to connect with the film today. Keam says this connection is the result of "teen female fans' engagement with Danes's starbody," a somewhat androgynous body that links her back to her role on the popular television series, My So Called Life. ${ }^{4}$ DiCaprio's star-body is similarly androgynous, and the film works to make the two lovers mirror images of one another. This mirroring also links Shakespeare's story to the classical tale of Narcissus, the young boy who adored his own reflection. Luhrmann's use of mirrors and reflections, through glass and water, suggests that the love of "Juliet and her Romeo" is similar to narcissistic love of the self (V.iii.309). ${ }^{5}$

2 It is misleading, perhaps, to title this paper "Juliet's Narcissism," because, as I will argue, Romeo becomes the narcissistic reflection of Juliet. In addition, Luhrmann's film focuses more on Romeo than it does on Juliet, and any discussion of her characterization requires substantial discussion of his. ${ }^{6}$ But, in a narcissistic reading of this play and film, Juliet and Romeo frequently merge into one. And, in the end, it is Juliet who attempts to shift their relationship from love of the self to love of an "other," even though doing so necessitates their death. In her recent survey of the "burgeoning field of Shakespeare and Girls' Studies," Jennifer Higginbotham remarks that Juliet (although second to Ophelia in this regard) has "functioned as an archetype for contemporary psychoanalytic accounts of adolescent girls." I would like to consider what Luhrmann's Juliet, her Romeo, and the story of their "death-marked 
love" teaches viewers-particularly girls-about selfhood, love, hate, and death (Prologue.9). But my focus in this essay is on narcissistic imagery in Luhrmann's film and in Shakespeare's play.

3 For context, it is helpful to review Ovid's tale of "Narcissus and Echo" from his Metamorphoses. Narcissus is the son of the river nymph Liriope. When a "prophetic seer was asked whether" Narcissus "would live to a ripe old age, he replied: 'Yes, if he does not come to know himself."' ${ }^{8}$ When Narcissus is sixteen, many boys and girls love him, including Echo, the young girl who can only repeat the final few words of phrases others speak. She follows Narcissus, begins echoing his calls, but when she tries to embrace him, he denies her advances; so she retreats to a cave, withers away, and all that remains is her echoing voice. Narcissus is then cursed by Nemesis for playing with the affections of others. Soon after the curse, Narcissus takes a break from hunting to rest by a clear pool. He leans down to drink and becomes enchanted by his reflection. He is "spellbound by his own self"; 9 he cries, he pines, and he becomes more and more desperate to embrace his reflection; eventually, his love causes his body to waste away. 10

Certainly, Shakespeare was greatly influenced by Ovid, including the story of Narcissus. ${ }^{11}$ Eric Langley argues that Shakespeare probably did not use Arthur Golding's 1565 translation of Ovid, in which Narcissus is un-poetically described as a "foolish noddie." ${ }^{12} \mathrm{He}$ points to the rhetorically reflective description of Narcissus in Venus and Adonis ("Narcissus so himself himself forsook, / And died to kiss his shadow in the brook," l. 161-162), to propose that "Shakespeare takes his cue from the source text itself [...] with a suggestively condensed rhetorical figure" in the repetition of "himself himself." ${ }^{13}$ Here, my aim is not to present a source study of either Shakespeare's or Luhrmann's classical references. Rather, I want to show how there are similarities in Ovid's, Shakespeare's, and Luhrmann's presentations of narcissistic and true love. Simply put, both Narcissus and his image, and Juliet and Romeo, fall in love with the forbidden and die tragically from this love. Luhrmann cuts all of the classical references from his adaptation, perhaps assuming the limited knowledge of his contemporary, specifically teen, audience, and instead makes these references visible through imagery.

In the film, we first view Juliet from underwater: "Juliet is introduced to the viewer through an extreme close-up as she floats suspended in the bathtub, strands of hair framing her face, which the water slightly blurs. Here, Danes establishes a direct gaze with her fan, inviting the filmgoer into her private underwater world." ${ }^{14}$ Juliet is sucked out of this private oasis by the screeching calls of her mother and nurse, who invite her to consider Paris's advances at the evening ball. This introduction suggests that Juliet is more comfortable in her quiet, introspective, underwater world than she is in the loud, performative reality of the Capulets. Like Narcissus, Juliet prefers to remain in her own, self-reflective space.

In the film's opening scenes, Romeo is shown to be more social with Benvolio, Mercutio, and the Montagues, but only after we see him smoking cigarettes and writing poetry alone in the sycamore grove. Romeo's own escape to a self-reflective, underwater space leads him to Juliet. Romeo is at the Capulet ball, drugged on a hallucinogen, when the room begins to spin. He retreats to a bathroom, where we now see an extreme close-up of his face, submerged in a sink full of water. The image mirrors our introductory image of Juliet, but Romeo's underwater world is not peaceful; his eyes are wide and his mouth gasps bubbles. Panicked, he raises his face to a mirror, removes the silver mask 
that had been pushed to his hairline, and throws it in the sink. He calms down, glances at his mirrored image, and then, with a slightly confused expression, looks beyond his reflection and notices something behind him..$^{15}$

7 Romeo turns around and approaches a large aquarium filled with tropical fish. Intrigued, he follows the fish with his eyes and then leans down to look beneath a coral bridge. His eye is shown framed in the coral, and then the camera cuts to another eye, also framed in coral. For a second, the two eyes appear to be two different shots of Romeo. But when both Romeo and Juliet abruptly stand, we realize that the second eye is Juliet's, visible from the other side of the aquarium. They stare at each other, lips slightly parted, with looks of shock and desire, with what is best described as love at first sight. The camera, from a perspective inside the aquarium, cuts back and forth between images of their faces, blurred colors of fish floating in front of them. Then, returning to his side of the tank, the camera shows Romeo gazing at Juliet's slightly distorted image through the water, alongside a reflection of himself. As he moves towards her image, his reflection follows and aligns itself on top of Juliet. She smiles, moves back, and Romeo presses his nose to the glass and to his reflected face. The camera then travels horizontally through the aquarium and emerges on Juliet's side of the tank. She shyly glances down, and then looks back to the tank, first at her reflection and then to Romeo behind the wall of water. They both smile again, and then Juliet's nurse, announcing that her mother is calling, snatches Juliet's hand, and pulls her away from the aquarium.

8 In this scene, Luhrmann's use of mirrors and reflections gestures towards the story of Narcissus and his beloved image. Lurhmann's adaptation suggests that true love is narcissistic because it is about the development of lovers' subjectivities. Their "I"s, their self-identities, are established through their eyes and, then, language. For instance, Matthew Spellberg imagines that when Romeo first sees Juliet, "language is born, as if to say, I see Juliet; now I may imagine; and through imagining, speak." ${ }^{16}$ But something is inherently tragic about this development because one cannot be a subject without an other. This "other" reveals what the "I" is not or cannot have. Realizing the self is also realizing the non-self, or the possibility of death. Julia Kristeva describes the love in this play as "ephemeral happiness," because the lovers "spend less time loving each other than getting ready to die." ${ }^{17}$ For Kristeva, there is an "intrinsic presence of hatred in amatory feeling itself. [...] As soon as an other appears different from myself, it becomes alien, repelled, repugnant, abject-hated." ${ }^{18}$ Both the classical tale and the filmed play show birth (of "self" versus "other"), love, hatred, and death to be the same moment. Through Luhrmann's reflective imagery, the story of Romeo and Juliet surfaces as a story of narcissistic love.

9 Although a narcissistic reading of the play ends (primarily) with Juliet, it begins with Romeo. Like Narcissus, Romeo exists within a liminal space at the age of sixteen, where he is neither boy nor man. ${ }^{19}$ Pining for the love of Rosaline, Romeo has withdrawn to a sycamore grove: "Many a morning hath he there been seen, / With tears augmenting the fresh morning's dew, / Adding to clouds more clouds with his deep sighs" (I.i. 128-130). Like Narcissus, Romeo cries for his unfulfilled and seemingly tragic desire. Already, a relationship between love and liquid is established, which is a relationship that defines narcissism, and inspires Luhrmann's film.

Romeo's initial love of Rosaline admits a stalemate of unequal desire and love that functions as Romeo's point of departure. The desire to conquer Rosaline is replaced by 
a desire to touch Juliet: "I'll watch her place of stand, / And, touching hers, make blessèd my rude hand" (I.v.49-50). He later wishes away his own identity and desires to be a glove that touches her cheek. Narcissus's desire to touch his image is what also reveals his love for himself. Burning with love, he reaches to the water and tries to kiss and embrace his reflection. ${ }^{20}$ In Shakespeare's play, the desire to touch replacing the impulse to conquer is significant because it suggests an emerging equality. For Romeo to touch Juliet's hand requires Juliet to touch Romeo's, and, as we learn, she is eager to do so. Juliet's return of love, unlike Rosaline's dismissal, leads Romeo to address his new love as his very soul, or his self. He says, "How is't, my soul? Let's talk" (III.v.25). Instead of the subject conquering the object, the two, subject and object (Romeo and Juliet), become one. The self is found within the other. As Luhrmann depicts, Romeo removes his mask and looks at himself in the mirror before seeing Juliet. Without the mask, without the blinding power of Rosaline, Romeo can see his reflection clearly. Juliet always had a clear view. When Romeo sees the aquarium in the mirror and abruptly turns around, this movement could be read as a search for both the fish and his own image. He does find his reflection among the fish, at the same time as his discovery of the image of Juliet. When the two see each other, the camera focuses on the mirror images of their single eyes through the water and the single eyes of Romeo and Juliet become one pair. In this first gaze, the two lovers become one. Like Romeo, Juliet was likely in the bathroom to escape (or, she just needed to use the facilities); but I like to think she was drawn to the aquarium for similarly self-reflective reasons (or, even better, she was actively seeking someone to spy on in the boys' room). Luhrmann does not give us Juliet's perspective until the two lock eyes, but it is tempting to think that her active gaze attracts Romeo. Like Narcissus and his reflection, both images actively pursue the other.

11 Benvolio had described Romeo's eyeballs as a scale where Rosaline was "Herself poised with herself in either eye" (I.ii.97). Instead of replacing Rosaline with Juliet in one of his eyes, we find Juliet and Romeo sharing their visions of each other. The eye becomes equally important in this exchange of gazes as it both figures as a liquid mirror that reflects the person who gazes upon it, and through emotional expression provides a window to a person's soul. Romeo and Juliet see one another in each other's eyes, but also reveal their desire through their visual exchange. To complicate this, however, Sharon MacIsaac suggests that the lover "loves himself in the eyes of another." ${ }^{21}$ The locked gaze of lovers offers a feedback loop of sorts: Not only does the eye behold actively the eye of the other, but it also beholds the responsive beholding of the other's eye. That is, the eye not only sees, but sees itself seeing, and, as MacIssac suggests, both loves what it sees and loves itself seeing. ${ }^{22}$

12 A Lacanian reading is apt here too; when Luhrmann's Romeo and Juliet play with their overlapping images at the fish tank, it is as though they are in the mirror stage of "jubilant assumption [...] prior to being objectified in the dialectic of identification with the other, and before language restores to it, in the universal, its function as subject." ${ }^{23}$ Lacan was describing pre-verbal infants, but Romeo and Juliet's lack of knowledge and silent exchange make this parallel worth considering. In Lurhmann's depiction of love at first sight, the only exchange is visual. Romeo and Juliet neither speak nor touch. This is appropriate because, like Narcissus, Romeo and Juliet are not yet separate subjects. Their reflected images of themselves are inseparable from the water-distorted images of each other. All four images shift in the water and merge into one. The movements of Juliet and Romeo on opposite sides of the aquarium echo Ovid's description of 
Narcissus: "Only a little water keeps us apart. My love himself desires to be embraced: for whenever I lean forward to kiss the clear waters he lifts up his face to mine and strives to reach me. [...] you laugh when I do." ${ }^{24}$

When Narcissus speaks here, he speaks exclusively to himself. Likewise, when Romeo finally addresses the image of Juliet, he speaks in soliloquy: "Did my heart love till now? Forswear it, sight, / For I ne'er saw true beauty till this night" (I.v.51-52). Romeo speaks of his sight as separate from himself; the "eye" and the "I" of both Romeo and Juliet have been joined in their initial visual exchange. When they do speak to each other, their conversing only strengthens their bond. Juliet does not simply listen to Romeo's words, but she replies and demands active engagement. Together, they write a sonnet amidst kisses, and then begin a second one that is cut short by Juliet's Nurse:

ROMEO. Thus from my lips, by thine my sin is purged.

JULIET. Then have my lips the sin that they have took.

ROMEO. Sin from my lips? O trespass sweetly urged!

Give me my sin again. He kisses her

JULIET. You kiss by th'book.

I.v.106-109

14 Romeo and Juliet write their love through poetry. They also establish their subjectivities, as suggested by Emile Benveniste, through speaking the "I" and the "you": "Language is possible only because each speaker sets himself up as a subject by referring to himself as $I$ in his discourse. Because of this, I posits another person, the one who, being, as he is, completely exterior to 'me,' becomes my echo to whom I say you and who says you to me."25

In Ovid's tale, when Echo pursues Narcissus, she does so secretly at first, and the young girl can only repeat the last words that Narcissus has spoken. Because she can only echo, she cannot provide the "other" necessary for Narcissus to establish his, or her, subject self. When he asks to meet her, she responds in kind-“Let us meet!"-but when she comes out of hiding and attempts to embrace him, he says "Away with these embraces! I would die before I would have you touch me!" Echo echoes her response, "I would have you touch me!"26 Echo's echoes are selective; in this scene, she expresses her desires within the confines of her desire's-Narcissus's-utterances. When Echo echoes "Let us meet!," her words echo Narcissus's, but when she speaks of her desire for Narcissus to touch her, her words act more like a mirror image by reflecting the opposite of Narcissus's desire. His hatred and her love are expressed by the same, echoed phrase.

Juliet echoes some of Romeo's phrasings in the sonnet exchange, but no more than Romeo echoes Juliet's, and this doubling of echoes aligns Shakespeare's couple with Narcissus and Narcissus more than with Narcissus and Echo. Both Romeo and Juliet actively speak, touch, and kiss one another, unlike Echo, who is denied, hated, and retreats into her cave. The sonnet exchange represents the last words Romeo and Juliet speak to one another before they realize they come from warring families and then meet again for the so-called balcony scene. Hatred echoes love.

In a fascinating move, Luhrmann removes Juliet from her balcony and locates this scene around and in a swimming pool that is landscaped with cave-like grottos. Juliet mimics Narcissus's fatal action-she becomes Narcissus-when she crouches down by the pool, gazes in the water, and asks, "what's in a name?" (II.i.85). At this most narcissistic moment, Juliet questions Romeo's identity. She does offer to sacrifice her 
Capulet nature for him too, but she is more interested in figuring out how to love the most hated "other." Romeo then approaches Juliet by the pool, she screams, slips, and the two fall into the water. While in the pool, the young lovers admit their love for each other and exchange vows. When Romeo does propose marriage (after Juliet's urging), they embrace in an underwater kiss.

In Luhrmann's reimagined balcony scene, Juliet, like Narcissus, speaks directly to her watery reflection. But, with the realization of their family's enmity, like Narcissus's recognition that the image is himself, Romeo and Juliet's discourse begins to falter. The lovers no longer write sonnets when then speak. They begin to speak at odds. Romeo focuses on Juliet's beauty and the insurmountable power of his love, where she expresses fear they will be caught, the problem of their family names, and a concern that she unknowingly revealed her love. In a Lacanian reading, the mirror stage has come to an end: "It is this moment that decisively tops the whole of human knowledge [savoir] into being mediated by the other's desire, constitutes its objects in an abstract equivalence due to competition from other people, and turns the I into an apparatus to which every instinctual pressure constitutes a danger." ${ }^{27}$ Simply put, the end of the mirror stage is the beginning of tragedy. Edward Snow contends that at the Capulet ball, when Romeo and Juliet meet, they are like "two exposed, vulnerably embodied selves reaching out tentatively across sexual difference and social opposition, while their imaginations mingle in an intersubjective privacy that weaves its boundaries protectively around them." ${ }^{28}$ After the ball, their language continues to echo each other's words; there are "elaborately matched images and turns of phrase that link their separate speeches." ${ }^{29}$ For instance, "Romeo tells Juliet he has 'night's cloak' to hide him from her kinsmen (II.ii.75); a few moments later she informs him that 'the mask of night' is on her face' (II.ii.85)." ${ }^{30}$ But, Snow claims, the echoes finally mark more difference than similarity, and this difference is the difference between the sexes. ${ }^{31}$ Perhaps this brings us back to Narcissus and Echo, and the fact that Echo's desires are an exact mirror of Narcissus's dismissal; they speak the same words but to different purposes.

19 Luhrmann describes his Romeo as a "Byronesque rebel in love with the idea of love itself." ${ }^{32}$ This love of love, as Jonathan Bate notes, is a state approaching the self-love of Narcissus. ${ }^{33}$ There is something childish about, not just Romeo's love of Rosaline, but also of Juliet. Or, perhaps it is just that Juliet seems so mature. Evelyn Gajowski writes, "Shakespeare's female protagonists are [...] articulate, active partners in love. And 'to speak,' as Catherine Belsey reminds us, 'is to become a subject." ${ }^{34}$ Spellberg says that Romeo becomes a speaking subject the moment he sees Juliet. ${ }^{35}$ Because Juliet is a girl, her establishment of subjectivity is a bit more complicated. In Shakespeare and the Performance of Girlhood, Deanne Williams offers Juliet as an example of one of Shakespeare's characters who is labeled as a "girl" in part because she is independent, willful, and resistant. ${ }^{36}$ Williams explains that, for Renaissance girls, "to be peevish and perverse [like Juliet] is not only to perform their status as girls, but also, through resistance and mutability, to become themselves." ${ }^{37}$ Juliet establishes her subjectivity by acting against her father and her name, but also by speaking for herself. At first, she completes Romeo's poetry, but in the balcony/pool scene she serves as a voice of reason. When she speaks of love, Juliet guides Romeo towards concrete talk of vows and marriage rather than emotion and compliment. As Gajowski indicates, Juliet "makes possible a love that surpasses narcissistic desire and its failure to connect with the reality of the other." ${ }^{38}$ Does Juliet thus pull Romeo away from Rosaline and his original 
narcissism? What about Juliet's narcissism? Is Romeo and Juliet's relationship no longer narcissistic? Do they simply see each other as objects? Shakespeare's play and Luhrmann's film complicate this conclusion. There is something narcissistic about finding equality and reciprocity in their relationship. What makes their love "true" is that they see each other as objects, but within their own subjectivities.

Juliet steers Romeo to the stable path of vows, and, through the performative act of swearing, they enact a promise to marry ${ }^{39}$ Juliet initially questions the truth-value of Romeo's swearing. In fact, she asks him either not to swear at all, "Or, if thou wilt, swear by thy gracious self" (II.i.155). Romeo responds by kissing Juliet; he does not swear verbally. The linguistic act of swearing is superfluous, or even worse, would presume and establish distrust. In Luhrmann's film, when Romeo and Juliet "perform" their engagement, it is sealed with an underwater kiss. Unlike Narcissus, when Romeo and Juliet break the surface of the water and the initial wall and mirror of the aquarium, they find solid "others." In a way, this is the materialization and satisfaction of narcissistic desire; Romeo and Juliet are more narcissistic than Narcissus.

Narcissus is not mentioned by name in Shakespeare's play, but Echo is, and as a sort of soul sister to Juliet. After the engagement, and before the lovers part ways, Juliet summons Echo, while calling out to her Romeo:

Bondage is hoarse, and may not speak aloud,

Else would I tear the cave where Echo lies,

And make her airy tongue more hoarse than mine

With repetition of my Romeo's name. Romeo!

II.i.205-208 ${ }^{40}$

Bate argues that Juliet is in "concomitant linguistic imprisonment" and feeling trapped by girls' traditional roles as passive love objects and controlling fathers. ${ }^{41}$ She calls out his name to free herself from this prison of language, while saying she cannot, but proving she can. Juliet already has begun reverberating echoes of Romeo's name-“O Romeo, Romeo, wherefore art thou Romeo" (II.i.75) - not knowing that he was listening, but claiming a connection with him and, by speaking his "you," subjectivity for herself. Where Echo could not provide an "other" for Narcissus, Juliet can for Romeo. The "other" is both Juliet as an independent, speaking subject, and Juliet as Romeo's own self. In between a mention of his name and Juliet's echo of it, Romeo says, "It is my soul that calls upon my name" (II.i.209). Unlike Narcissus, Romeo recognizes that the voice calling his name is both his soul's and his Juliet's. But, like Narcissus, even with this recognition that the self is the love object, Romeo and Juliet continue to love.

The picture of love painted by Shakespeare and Luhrmann is more complicated than a displacement of narcissism. In Ovid's myth there is something about being itself that is narcissistic. And this being necessitates death, or not being..$^{42}$ Maurice Blanchot explains that Ovid's narrative is not chronological, but acts as its own mirror in repetitions. ${ }^{43}$ Narcissus's recognition of the image, the birth of his self-consciousness, his tears, and his death are all one moment. The text liquefies, as does Narcissus at the end of his tragic tale. When Romeo and Juliet realize each other's identities, Juliet says:

My only love sprung from my only hate!

Too early seen unknown, and known too late!

Prodigious birth of love it is to me

That I must love a loathèd enemy.

I.v.137-140 
It is upon this one moment that the rest of the text reflects. ${ }^{44}$ The fact that Juliet is the one who speaks these pivotal lines is telling. When Romeo learns that he has fallen in love with the forbidden, he remarks, "Is she a Capulet? / O dear account! My life is my foe's debt" (I.v.116-117). Benvolio interrupts Romeo (in Luhrmann's interpretation, it is Mercutio), urging him to leave the party. Both Romeo and Juliet speak of the ominous nature of loving the enemy, but Shakespeare gives Juliet the more complex poetry. Her lines do similar reflective work to the "himself himself" construction Shakespeare used in Venus and Adonis to describe Narcissus's self-love. Thus, Juliet is the one linked with narcissistic love, but not just as a participant in it; she is the one who has linguistic control over it. Williams looks at the "spaces between the actions that shape the play" and argues, "Juliet distinguishes herself as a deep and original thinker." ${ }^{45}$ Romeo, by contrast, follows her lead. For instance, when Romeo threatens Balthazar with seemingly masculine violence at the tomb, his threats mirror the same ones Juliet made against herself to the Friar; thus, Williams argues, love has made Romeo "more like his own wild and fearless girl, Juliet." "Juliet is the defining subject of Shakespeare's play.

The joining of Juliet and Romeo's eyes in their first visual encounter establishes a single subjectivity, or "I," that is always already problematic. Their prescribed hate necessitates a recognition of the "other," and so a realization of difference and lack. Within this is recognition of the self, and, consequently, the non-self. Only in death do Juliet and Romeo fully return to their love at first sight. Their death mirrors the birth of their love; and, because the two subjects are one again, Romeo and Juliet die at the same moment. Langley shows how the play works towards a single stage direction: "The irresistible pull of sympathetic attraction towards the fusion of double-self, with its concomitant effacement of each individual subjectivity, has brought the lovers to this conclusion: '[Falls on Romeo's body and dies]'." ${ }^{47}$ Luhrmann reworks the text to bring their deaths as close as possible. Juliet awakens from feigned death and reaches up to touch Romeo's cheek. At this exact moment, he swallows the poison. They cry together when they realize their fatal mistake, Romeo speaks the last words-"Thus with a kiss I die" (V.iii.120)-and then he dies. Juliet continues to cry for a minute, and then, without speaking, she shoots herself. Luhrmann gives Romeo, the Narcissistic boy, the final words, but Juliet's inability to speak after he perishes makes sense whether she is like Echo or Narcissus's own reflection. Without her "other," she cannot utter. The final image of the two lovers is a flashback to their underwater kiss. In death, Romeo and Juliet remain frozen underwater in an embrace that symbolizes both the realization and joining of their subjectivities. Through water, Juliet and Romeo narcissistically discover themselves, each other, love, hate, and death.

What, finally, does Shakespeare's play and Luhrmann's adaptation teach girls about selfhood, love, hate, and death? It is unlikely many teen readers or viewers would parse out the complex narcissistic imagery considered here, but I believe this imagery ends up empowering girls, albeit problematically so. The problems, of course, are that girls are taught they need boys to discover themselves, that such self-discovery results in death, and that the self cannot continue without its beloved other. But Juliet is not a passive recipient of male desire; she is at least an equal player in love; she is the mirror image of her beloved Romeo. But, perhaps more than this, she is the subject that manages their dual-self. Although Juliet only comes to an awareness of her own subjectivity through Romeo, Romeo is a reflection of her self, and thus it is self-love 
that creates her identity. Death might be the inevitable end to this story, but the narcissistic imagery reminds us that this death is symbolic, or the stuff of mythology.

\section{NOTES}

1. William Shakespeare's Romeo+Juliet, directed by Baz Luhrmann, Los Angeles, CA, 20th Century Fox, 2002, DVD. Julian Fellowes' 2013 adaptation might become the new classroom standard, but considering its chilly reception, this seems unlikely. See Claire Duffin, "Romeo, Romeo, what's Julian Fellowes done to you?," The Telegraph (1 September 2013), accessible online at: http:// www.telegraph.co.uk/culture/theatre/william-shakespeare/10278154/Romeo-Romeo-whatsJulian-Fellowes-done-to-you.html, last accessed 28 August 2015. Duffin notes that scholars from both the Folger Shakespeare Library and the Shakespeare Institute criticize Fellowes' amendments of and additions to Shakespeare's text. See also Susan Wloszczynz, "Review: Romeo and Juliet," RogerEbert.com (11 October 2013), accessible online at: http://www.rogerebert.com/ reviews/romeo-and-juliet-2013, last accessed 28 August 2015. Wloszczynz summarizes the popular response to the film when she bluntly states, "It might be easier to simply mention what isn't terrible first."

2. Angela Keam, “The 'Shakesteen' Genre: Claire Danes's Star-Body, Teen Female Fans, and the Pluralization of Authorship," Borrows and Lenders: The Journal of Shakespeare and Appropriation, vol. 2, Spring/Summer 2006 (accessible online at: http://www.borrowers.uga.edu/781413/show, last accessed 31 August 2015).

3. Ibid.

4. Ibid.

5. William Shakespeare, The Most Excellent and Lamentable Tragedy of Romeo and Juliet, in John Jowett, William Montgomery, Gary Taylor, and Stanley Wells, ed., The Oxford Shakespeare: The Complete Works, $2^{\text {nd }}$ ed., Oxford, Oxford University Press, 2005, p. 369-400. All references to the play (and other Shakespearean works) come from this edition and are cited in the text.

6. Lindsey Scott, “'Closed in a Dead Man's Tomb': Juliet, Space, and the Body in Franco Zeffirelli's and Baz Luhrmann's Films of Romeo and Juliet," Literature/Film Quarterly, vol. 36, 2008, 137-146 (p. 141). Scott argues that Luhrmann's film "features a Juliet who is oddly lacking in the desire and agency of Shakespeare's heroine" (p. 141). She is a "picture of stillness" (p. 141).

7. Jennifer Higginbotham, "Shakespeare and Girlhood," Literature Compass, vol. 10, 2013, 189-200 (p. 189, p. 197).

8. Ovid (Publius Ovidius Naso), "Echo and Narcissus," Metamorphoses, translated by Mary M. Innes, London, Penguin, 1955, III.343-492 (III.348-350).

9. Ibid., III.419.

10. Ibid., III.414-492.

11. See Jonathan Bate, Shakespeare and Ovid, Oxford, Clarendon Press, 1993. As shown by Bate, Shakespeare made extensive use of Ovid's works, which he knew quite well both in the Latin original and via Elizabethan translations, in his plays and poetry. See also Sarah Annes Brown, Ovid: Myth and Metamorphosis, Bristol, Bristol Classical Press, 2005; A.B. Taylor, ed., Shakespeare's Ovid, Cambridge, Cambridge University Press, 2006; and Colin Burrow, Shakespeare and Classical Antiquity, Oxford, Oxford University Press, 2013. 
12. Eric Langley, Narcissism and Suicide in Shakespeare and his Contemporaries, Oxford, Oxford University Press, 2009, p. 29.

13. Ibid., p. 33

14. Keam, op. cit.

15. The scene can be viewed here: https://www.youtube.com/watch?v=bApvA8me8q0 (last accessed 1 September 2015).

16. Matthew Spellberg, "Feeling Dreams in Romeo and Juliet," English Literary Renaissance, vol. 43, Winter 2013, 62-85 (p. 77).

17. Julia Kristeva, "Romeo and Juliet: Love-Hatred in the Couple," Tales of Love, translated by Leon S. Roudiez, New York, Columbia University Press, p. 209-233 (p. 210) (Histoires d'amour, Paris, Denoël, 1983).

18. Ibid., p. 222.

19. Ovid, op. cit., III.344.

20. Ibid., III.427-429.

21. Sharon MacIssac, "Narcissism," in Freud and Original Sin, New York, Paulist Press, 1974, p. 87-99 (p. 94).

22. See Douglas Trevor, "Love, Humoralism, and 'Soft' Psychoanalysis," Shakespeare Studies, vol. 33, January 2005, 87-94. He similarly argues, "narcissism is a fundamental attribute of love, insofar as lovers project their own images and wants onto the objects they love, rather than erasing or supplementing their own identities with that of the other," and says this is something Shakespeare "exploits" in Romeo and Juliet (p. 91).

23. Jacques Lacan, "The Mirror Stage as Formative of the I Function," in Écrits: The First Complete Edition in English, translated by Bruce Fink, New York, Norton, 2006, p. 75-81 (p. 76) (Écrits, Paris, Seuil, 1966).

24. Ovid, op. cit., III.450-460.

25. Emile Benveniste, "Subjectivity in Language," in Problems in General Linguistics, translated by Mark Elizabeth Meek, Coral Gables, University of Miami Press, 1971, p. 223-230 (p. 225) (Problèmes de linguistique générale, Paris, Gallimard, 1966, 1974).

26. Ovid, op. cit., III.387-392.

27. Lacan, op. cit., p. 79.

28. Edward Snow, "Language and Sexual Difference in Romeo and Juliet," in John F. Andrews, ed., Romeo and Juliet: Critical Essays, New York, Garland, 1993, p. 371-401 (p. 371).

29. Ibid., p. 372. See also Langley, op. cit., p. 128.

30. Snow, op. cit., p. 372.

31. Ibid., p. 373.

32. William Shakespeare's Romeo + Juliet, directed by Baz Luhrmann, Promotional Packet Essay, Los Angeles, CA, 20th Century Fox, 1996, p. 9.

33. Bate, op. cit., p. 146.

34. Evelyn Gajowski, The Art of Loving: Female Subjectivity and Male Discursive Traditions in Shakespeare's Tragedies, Newark, University of Delaware Press, 1992, p. 21.

35. Spellberg, op. cit., p. 77.

36. Deanne Williams, Shakespeare and the Performance of Girlhood, New York, Palgrave, 2014, p. 6.

37. Ibid., p. 25.

38. Gajowski, op. cit., p. 40.

39. See Carolyn E. Brown, "Juliet's Taming of Romeo," Studies in English Literature, vol. 36, Spring 1996, 333-355. Brown argues that Shakespeare uses falconry imagery to show how Juliet has control over Romeo and reverses the typical gender roles.

40. Lurhmann does not have his Juliet speak these lines, perhaps due to the projected teen audience of the film. But, the pool and cave visual imagery might connect, in part, to this specific classical reference. 
41. Bate, op. cit., 180.

42. Maurice Blanchot, The Writing of Disaster, translated by Ann Smock, Lincoln, University of Nebraska Press, 1986, p. 125-128 (p. 125) (L'Écriture du désastre, Paris, Gallimard, 1980).

43. Ibid.

44. See Lloyd Davis, "Death-Marked Love': Desire and Presence in Romeo and Juliet," in Shakespeare Survey, vol. 49, 1996, 57-68. Davis links the repetitive structure of the play to Petrarchan and other traditions of failed love, in addition to Ovid's Narcissus: "Repetitive designs through the play are used to underline the tension between desire and death" (p. 66). He argues, "Romeo and Juliet renovates tragic desire for the Elizabethans and for subsequent periods. In early scenes it evokes a narcissistic poetics of desire as self-loss and death but moves beyond that to stage a dialogic reciprocal presence" (p. 67). My suggestion here is that Juliet's role in bringing about this "dialogic reciprocal presence" is more significant than Romeo's.

45. Williams, op. cit., p. 48.

46. Ibid., p. 51.

47. Langley, op. cit., p. 135.

\section{ABSTRACTS}

In this paper, I consider what Baz Luhrmann's Juliet (Claire Danes), her Romeo (Leonardo DiCaprio), and the story of their "death-marked love" teach viewers about selfhood, love, hate, and death. It is frequently noted that Juliet demonstrates more maturity, but Luhrmann's 1996 film both confirms and complicates this reading by linking Shakespeare's play to Ovid's tale of "Narcissus and Echo." Luhrmann translates the play's classical references into visual images; he uses mirrors and reflections, through glass and water, to suggest that Romeo and Juliet's love for one another is very similar to narcissistic love of the self. It is Juliet who attempts to shift the relationship from love of the self to love of an "other," but doing so necessitates their death. My reading imagines a version of love that transcends the mirroring of a simply-thought and simplystructured narcissism and considers the problem inherent in linking the self to an "other" in relationships. Luhrmann's Juliet suggests that girls' love holds great power, but that self-love is what defines this power.

Cet article analyse les leçons enseignées aux spectateurs en matière d'identité, d'amour, de haine et de mort par l'histoire d'amour tragique de Roméo et Juliette (respectivement joués par Leonardo DiCaprio et Claire Danes) dans le film de Baz Luhrmann (Romeo+Juliet, 1996). Le réalisateur propose un traitement complexe de la plus grande maturité de Juliette en reliant la pièce de Shakespeare au récit ovidien concernant « Narcisse et Écho ». Les références classiques de la pièce deviennent des images dans la version de Luhrmann, qui utilise des effets de miroir, à travers l'eau et le verre, pour suggérer que l'amour qui naît entre Roméo et Juliette s'apparente à un amour de soi narcissique. Juliette tente d'opérer le passage d'un amour de soi à un amour de l'autre, mais cette tentative implique leur mort à tous deux. Au-delà d'un narcissisme primaire en miroir, mon analyse envisage une forme d'amour qui prenne en compte les difficultés d'une relation qui unit un individu à un autre. La Juliette de Luhrmann révèle le pouvoir de l'amour féminin, mais aussi le rôle essentiel de l'amour de soi dans la définition de ce pouvoir. 
INDEX

Keywords: film, girlhood, girls, Romeo and Juliet, Luhrmann Baz, Narcissism, Ovid

Mots-clés: filles, film, jeunesse, Luhrmann Baz, narcissisme, Ovide, Roméo et Juliette

\section{AUTHOR}

NATALIE K. ESCHENBAUM

University of Wisconsin, La Crosse 